\title{
Influence of Growth Impurities on Thermal Defect Formation in Monocrystalline Silicon
}

\author{
${ }^{I}$ Drogobych Ivan Franko State Pedagogical University, Drogobych, Ukraine, yu pavlovskyy@ukr.net \\ ${ }^{2}$ Institute for Nuclear Research, NAS of Ukraine, Kyiv, Ukraine
}

\begin{abstract}
The influence of growth impurities (oxygen and carbon) on the thermals defect formation in silicon single crystals has been studied. Annealing was carried out in the temperature range $700-1100^{\circ} \mathrm{C}$ in steps of $50{ }^{\circ} \mathrm{C}$ for 5 hours at each temperature. The magnetic, micromechanical and structural properties of annealed silicon single crystals have been experimentally studied. The distribution of defects formed at different annealing temperatures has been studied. The correlation between changes of magnetic susceptibility, microhardness and rearrangement of structural defects in crystals after their heat treatment is revealed. Concentrations and sizes of magnetically ordered clusters are estimated. Interpretation of the obtained experimental results is offered.
\end{abstract}

Key words: monocrystalline silicon, oxygen, carbon, magnetic susceptibility, microhardness, heat treatment.

Received 13 April 2021; Accepted 29 June 2021.

\section{Introduction}

Due to significant natural resources, relative cheapness, and the development of growing technologies, monocrystalline silicon remains one of the main functional materials of semiconductor electronics. Despite the achievements of technologies for the production of pure silicon single crystals, they still contain a significant concentration of growth impurities, the main of which are oxygen and carbon. They can significantly affect the radiation and thermal defects in silicon, and the performance of electronic devices designed on its basis, which is of scientific interest to many researchers. The mechanism of this effect is associated with the internal mechanical stresses that occur in the crystal due to the mismatch of the covalent radii of impurity atoms and intrinsic silicon atoms. Quite a large number of works have been devoted to these issues [1-5], but they have not conducted comprehensive studies using various experimental techniques.

In this work, the influence of oxygen and carbon impurities on the magnetic susceptibility (MS), microhardness and rearrangement of structural defects in monocrystalline silicon, which was subjected to heat treatment in the range of $700-1100^{\circ} \mathrm{C}$, is investigated.

\section{Experimental methods and calculations}

Three groups of samples grown by the Czochralski method (Cz-Si) were used for the experiment: samples with high carbon content $\left(n-\mathrm{Si}[\mathrm{C}]_{1}, n-\mathrm{Si}[\mathrm{C}]_{2}\right)$, and of industrial brand KEF-2. Samples were selected with approximately the same initial concentration of free charge carriers $(n)$. The initial parameters are shown in Table 1.

Heat treatment of the samples was performed in a tubular furnace in air in the temperature range 700 $1100^{\circ} \mathrm{C}$ in increments of $50^{\circ} \mathrm{C}$ for 5 hours at each temperature, followed by cooling in air. We believe that annealing in air does not affect the formation of bulk thermal defects in $\mathrm{Si}$, because the authors [6] found that oxidation of the sample surface can lead to additional generation of interstitial silicon atoms in volume of crystal only during two-stage heat treatments with repeated annealing at temperatures above $1100{ }^{\circ} \mathrm{C}$ for more than 10 hours. 
Initial parameters of the studied samples

\begin{tabular}{|c|c|c|c|c|c|}
\hline No & Materials & $\begin{array}{c}n, \\
10^{15} \mathrm{~cm}^{-3}\end{array}$ & $\begin{array}{c}N_{O}, \\
10^{17} \mathrm{~cm}^{-3} \\
(\text { IRA) }\end{array}$ & $\begin{array}{c}N_{C}, \\
10^{17} \mathrm{~cm}^{-3} \\
\text { IRA) }\end{array}$ & $\begin{array}{c}N_{C}, \\
10^{17} \mathrm{~cm}^{-3} \\
(\text { SIMS) }\end{array}$ \\
\hline 1 & $n-S i\left[C_{1}\right]$ & 2.0 & $8.0-9.0$ & 3.3 & 3.0 \\
\hline 2 & $n-S i\left[C_{2}\right]$ & 2.0 & $7.5-8.0$ & 0.8 & 0.7 \\
\hline 3 & KEF-2 & 2.1 & $7.5-8.0$ & $<0.2$ & $<0.2$ \\
\hline
\end{tabular}

The measurement of the magnetic susceptibility of the crystals was performed on an advanced setup [7] in magnetic fields $(0.3-4.0) \mathrm{kOe}$ at $290 \mathrm{~K}$. The maximum error did not exceed $1 \%$. Samples measuring $2 \times 3 \times 10 \mathrm{~mm}^{3}$ were prepared for MS measurements. The samples were ground with powders with a grain size of $12 \mu \mathrm{m}$ and $7 \mu \mathrm{m}$, polished with diamond paste with a grain diameter of 2 $\mu \mathrm{m}$, subjected to etching in a polishing etchant $\mathrm{HNO}_{3}: \mathrm{HF}$ $=4: 1$ and washed in distilled water.

Microhardness was measured by the Vickers method on the device PMT-3. On the basis of the device the subject table which has two degrees of freedom, a column with a carving on which the arm with a microscope and the loading device with an indenter is fixed is established. The Vickers indenter is a truncated quadrangular diamond pyramid with a square base and an angle at the apex between opposite faces of $136^{\circ}$. To accurately determine the number of microhardness, the optical axis of the microscope must coincide with the load axis when rotating the slide by $180^{\circ}$, ie it is necessary to adjust the optical system of the microhardness so that the print is applied exactly where it was selected under the microscope. It is also necessary to properly install the load mechanism in height. Height adjustment was performed on a standard with a known value of microhardness according to Vickers $\left(H_{V}\right)$. By adjusting the loading mechanism, it is necessary to obtain an imprint with a diagonal that would correspond to the microhardness of the standard. In our case, these are freshly chipped $\mathrm{KCl}$ crystals with known microhardness [8]. For a quadrilateral pyramid with an angle between opposite faces at the vertex $136^{\circ}$, the value of $H_{V}$ is calculated by the formula:

$$
H_{V}=\frac{P}{F_{\text {imp }}}=2 \frac{P}{d^{2}} \sin \frac{\alpha}{2}=1.8544 \frac{P}{d^{2}},
$$

where $H_{V}-$ Vickers microhardness, $\mathrm{kgf} / \mathrm{mm}^{2} ; P$ - load on the indenter, $\mathrm{kg} ; \alpha=136^{\circ}-$ angle at the top of the diamond pyramid; $d$ is the size of the diagonal of the imprint, averaged horizontally and vertically, $\mathrm{mm}$.

Used load $\mathrm{P}=0.1 \mathrm{~kg}$. The loading time of the diamond pyramid is 15 seconds. At least 20 indenter indentations were performed on each sample and the average values of the diagonal prints were calculated.

The study of structural defects and their reconstruction during heat treatment was performed using a metallographic instrumental microscope MIM-10. Before photographing, the samples were subjected to mechanical treatment (grinding with $7 \mu \mathrm{m}$ powder and polishing with diamond paste with a grain size of $2 \mu \mathrm{m}$ ) and chemical treatment in two stages: first in polishing etchant $\mathrm{HNO}_{3}: \mathrm{HF}=4: 1-5-10$ minutes, and then in selective etchant $\mathrm{HF}: \mathrm{CrO}_{3}=1: 1-20$ minutes.

\section{Experimental results and their discussion}

In Fig. 1 shows the dependences of the magnetic susceptibility on the magnetic field strength $(\chi(H))$ of the samples $\mathrm{Si}[\mathrm{C}]_{1}$ (Fig. 1, a) and KEF-2 (Fig. 1, b) after of the heat treatments in the range $700-1100^{\circ} \mathrm{C}$. It is seen that heat treatment leads to a decrease in diamagnetism
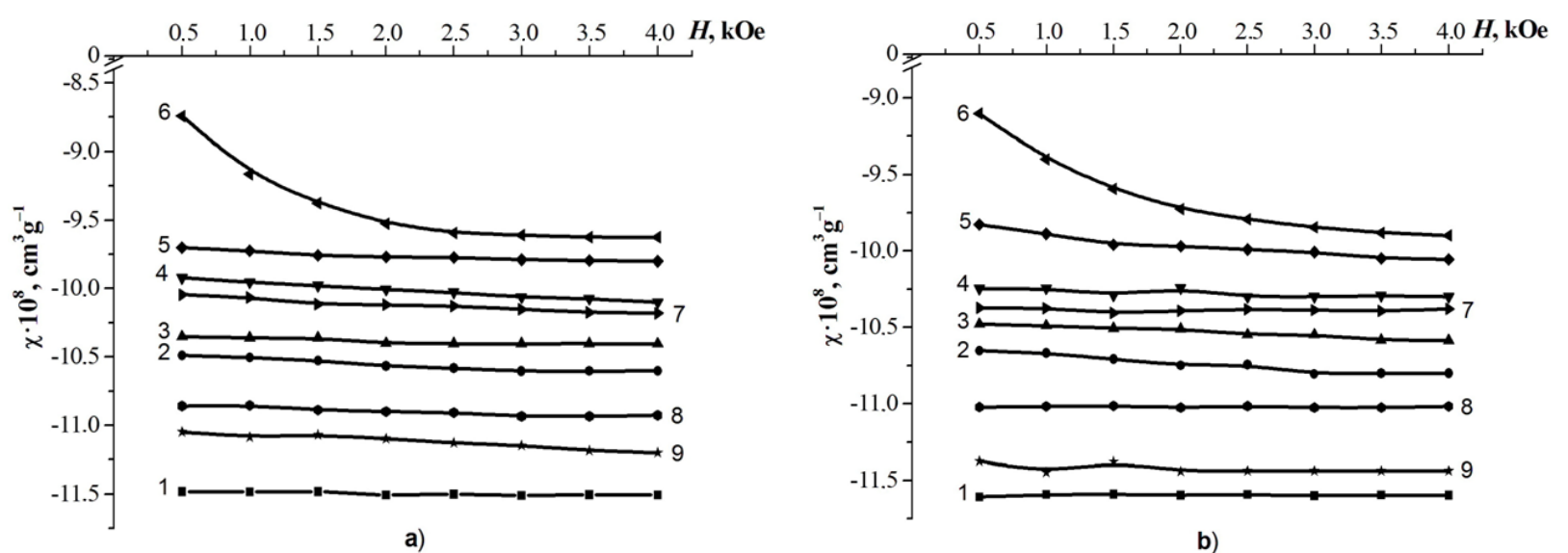

Fig. 1. Dependences of magnetic susceptibility on the magnetic field strength of samples $\mathrm{Si}[\mathrm{C}]_{1}(a)$ and $\mathrm{KEF}-2(b)$ after heat treatment: $1-$ not annealed, $2-700^{\circ} \mathrm{C}, 3-750{ }^{\circ} \mathrm{C}, 4-800{ }^{\circ} \mathrm{C}, 5-850{ }^{\circ} \mathrm{C}, 6-900{ }^{\circ} \mathrm{C}$, $7-950{ }^{\circ} \mathrm{C}, 8-1000{ }^{\circ} \mathrm{C}, 9-1100{ }^{\circ} \mathrm{C}$. 
relative to the original samples, with the maximum effect at $900{ }^{\circ} \mathrm{C}$. On the same samples there is a slight nonlinearity of the dependences $\chi(H)$.

In analyzing the experimental results, we assume that the effective values of the magnetic susceptibility of annealed samples are determined by the diamagnetic susceptibility of nominally pure silicon $\chi^{d}$ and the magnetic contribution of some defects $\chi^{\text {def }}$, which, in turn, consists of independent $\left(\chi^{p}\right)$ and of dependent on $H(\chi(H))$ components:

$$
\chi=\chi^{d}+\chi^{d e f}=\chi^{d}+\chi^{p}+\chi(H)
$$

For $\chi^{d}$ we take the value $\left(-11.6 \cdot 10^{-8}\right) \mathrm{cm}^{3} / \mathrm{g}$. Assuming that the value of $\chi^{d}$ does not depend on $H$, the difference between the values of $\chi$ and $\chi^{d}$ should be considered as the contribution of the defective subsystem of crystals. Thus, the decrease in diamagnetism is explained by the formation of paramagnetic centers in the process of heat treatment, and the nonlinearity $\chi(H)$ is explained by their magnetic ordering.

In Fig. 2 shows the value of magnetic susceptibility, in a field of $4 \mathrm{kE}(\chi(4.0))$, from the heat treatment temperature $\left(\chi\left(T_{\mathrm{TT}}\right)\right)$ of samples $\mathrm{Si}[\mathrm{C}]_{1}$ (curve 1 ), $\mathrm{Si}[\mathrm{C}]_{2}$ (curve 2) and KEF-2 (curve 3). It is seen that TT leads to the appearance of the paramagnetic component, which is most significantly manifested after annealing at $900^{\circ} \mathrm{C}$. Comparing the dependences $\chi\left(T_{\mathrm{TT}}\right)$ of samples with high carbon content with samples of the brand KEF-2, we see that the contribution of the paramagnetic component they have is approximately twice as large on epy all interval of heat treatments. It should be noted that the introduction of paramagnetic centers in the samples correlates with the content of optically active (atomic) carbon in them: the higher the concentration of carbon, the more paramagnetic centers are introduced (see Table 1).

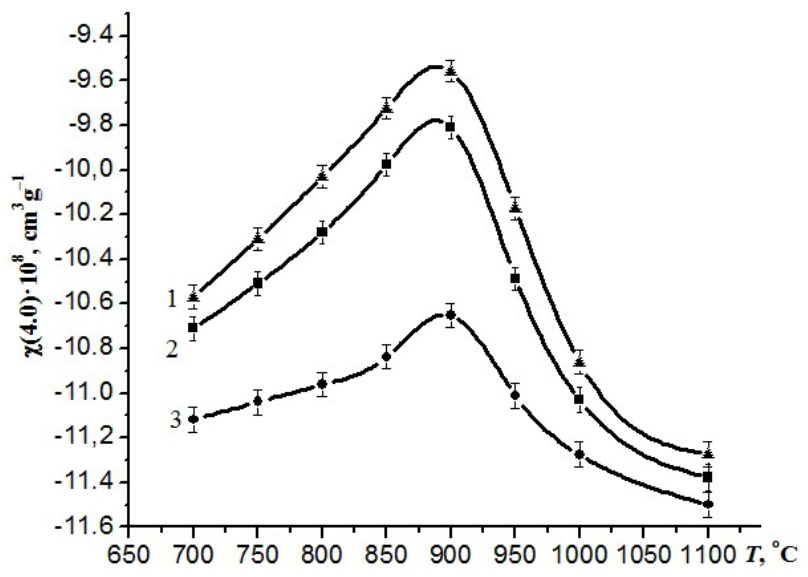

Fig. 2. Dependences of magnetic susceptibility on the temperature of heat treatment of samples: $\mathrm{Si}[\mathrm{C}]_{1}-$ curve $1, \mathrm{Si}[\mathrm{C}]_{2}$ - curve 2 and KEF- 2 - curve 3 .

In [9] it was noted that the influence of external factors such as magnetic field, radiation, and in our case thermal annealing, can stimulate the rupture in ties of Si$\mathrm{Si}, \mathrm{Si}-\mathrm{H}, \mathrm{Si}-\mathrm{C}, \mathrm{Si}-\mathrm{P}, \mathrm{Si}-\mathrm{B}$ in $\mathrm{SiO}_{\mathrm{x}}$-precipitates, which was recorded by EPR and Auger spectroscopy. In addition, it is known that already in the process of formation of the
$\mathrm{SiO}_{2}$ molecule, one interstitial silicon atom is generated [10]. The rupture of bonds and the subsequent evolution of the defective structure due to interdefective reactions results in the formation of clusters of interstitial silicon atoms. At the boundary of such clusters and $\mathrm{SiO}_{\mathrm{x}}$ precipitates with a crystal lattice of silicon, there are mechanical stresses, which leads to the formation of broken bonds (paramagnetic centers) at these boundaries, the concentration of which can exceed $10^{20} \mathrm{~cm}^{-3}$ [11].

It is known that carbon accelerates the precipitation of oxygen, and hence the above processes, which in turn leads to an increase in paramagnetism. It is possible that carbon, which is in a dissolved atomic state, is directly involved in the formation of paramagnetic centers. Such centers can be complexes consisting of two carbon atoms (located in adjacent lattice nodes) and an internodalsilicon atom (that is, $\mathrm{C}_{\mathrm{s}}-\mathrm{Si}_{\mathrm{i}}-\mathrm{C}_{\mathrm{s}}$ complexes), which in the excited triplet state correspond to the EPR spectrum of Si-PT1 [12].

The nonlinear dependence of $\chi(H)$ for samples annealed at $900^{\circ} \mathrm{C}$ may indicate the presence of "quasiferromagnetic" clusters that behave similarly to the Langevin paramagnetism of atoms with magnetic moment. The main difference is that their magnetic moment can be $10^{3}-10^{5}$ times greater than the magnetic moment of individual atoms. Thus for these samples, formula 2 can be written as:

$$
\chi=\chi^{d}+\chi^{p}+N \mu_{c l} L^{\prime}\left(\frac{\mu_{c l} H}{k T}\right),
$$

where $N$ is the concentration of magnetically ordered clusters; $\mu$ is the magnetic moment of one such cluster (we will assume in the first approximation that the magnetic moments of clusters are the same); $L^{\prime}(x)$ is the derived from the Langevin function, $k$ - Boltzmann constant, $T$ temperature. $\mu_{c l}=N_{0} \mu_{B} g \sqrt{s(s+1)}$, where $N_{0}$ is the number of paramagnetic centers in one magnetic cluster, $\mu_{\mathrm{B}}$ is the Bohr magneton, $g$ is the g-factor (for evaluation we take $g=2$ ), $\mathrm{s}$ is the spin of the paramagnetic center of which the cluster consists (for evaluation we take $s=1 / 2$ ).

A detailed description of the proposed model is presented in [13]. The parameters estimated on its basis are given in Table 2 .

In the model proposed above, we assumed, in the first approximation, that the magnetic moments of the clusters are the same. However, it is obvious that in reality this is not the case - there is a certain distribution by size:

$$
f\left(\mu_{c l}\right)=\frac{n}{\sqrt{2 \pi} \sigma} \frac{1}{\mu_{c l}} \exp \left[-\frac{\ln ^{2}\left(\mu_{c l} /\left\langle\mu_{c l}\right\rangle\right)}{2 \sigma^{2}}\right] .
$$

Table 2

Concentrations of magnetically ordered clusters $(N)$, the number of paramagnetic centers in one cluster $\left(N_{0}\right)$, and the ratio of magnetic moments of clusters to the Bohr magneton $\left(\mu / \mu_{\mathrm{B}}\right)$

\begin{tabular}{|c|c|c|c|}
\hline $\begin{array}{c}\text { No } \\
\text { sample }\end{array}$ & $\begin{array}{c}N, \\
\mathrm{~cm}^{-3}\end{array}$ & $N_{0}, 1 /$ cluster & $\mu / \mu_{\mathrm{B}}$ \\
\hline 1 & $2.7 \cdot 10^{11}$ & $4.0 \cdot 10^{3}$ & $6.7 \cdot 10^{3}$ \\
\hline 2 & $2.3 \cdot 10^{11}$ & $3.6 \cdot 10^{3}$ & $6.1 \cdot 10^{3}$ \\
\hline 3 & $1.4 \cdot 10^{11}$ & $3.2 \cdot 10^{3}$ & $4.8 \cdot 10^{3}$ \\
\hline
\end{tabular}


The distribution function $f(\mu)$ is defined by three parameters, i.e., $n, \sigma$, and $\left\langle\mu_{c l}\right\rangle$. This is described in detail by us in the works [14, 15]. Based on this model, the following results were obtained (Fig. 3). Maxima in Fig. 3 are the most probable values of the sizes and magnetic moments of clusters. As we can see, they satisfactorily coincide with the results obtained from model (3).

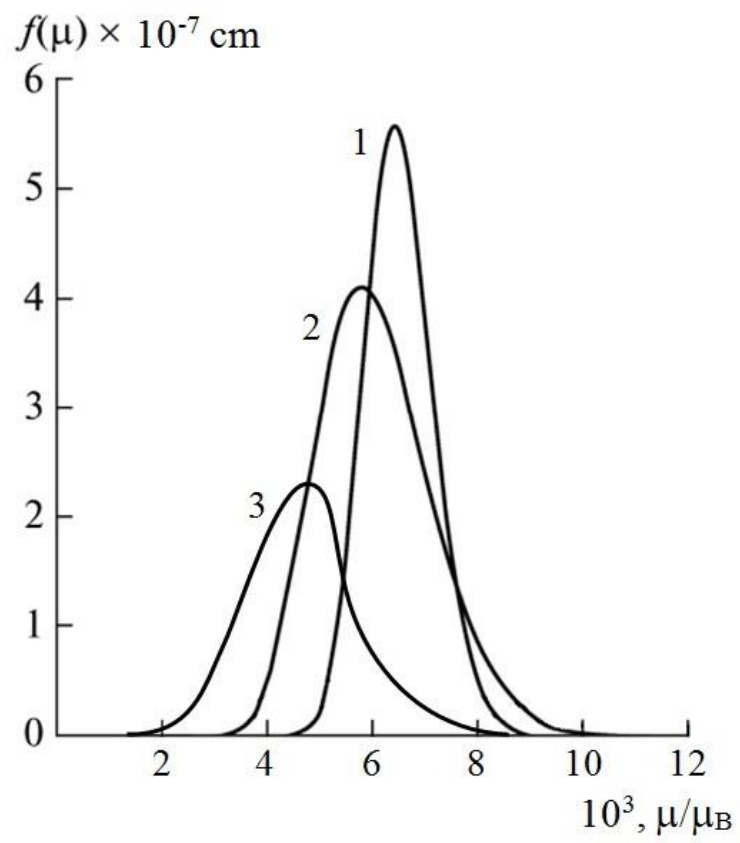

Fig. 3. Functions of distribution of clusters in samples for their big magnetic moments.

On the same samples Vickers microhardness $\left(H_{V}\right)$ was measured. The measurement results are presented in Fig. 4: samples $\mathrm{Si}[\mathrm{C}]_{1}$ (curve 1), $\mathrm{Si}[\mathrm{C}]_{2}$ (curve) and KEF2 (curve 3). Each point on the graphs is an average of 20 - 30 individual $H_{V}$ measurements. It is seen that in all cases, with increasing temperature from $700{ }^{\circ} \mathrm{C}$ to $900{ }^{\circ} \mathrm{C}$, the microhardness increases, and at annealing temperatures $T_{\mathrm{TT}}>900{ }^{\circ} \mathrm{C}-$ decreases and at $T_{\mathrm{TT}}=$ $1100^{\circ} \mathrm{C}$ approaches the initial value. This correlates well with the results obtained when measuring MS (Fig. 2) - in all cases, the maximum is achieved at a temperature of $T_{\mathrm{TT}}$ $=900{ }^{\circ} \mathrm{C}$.

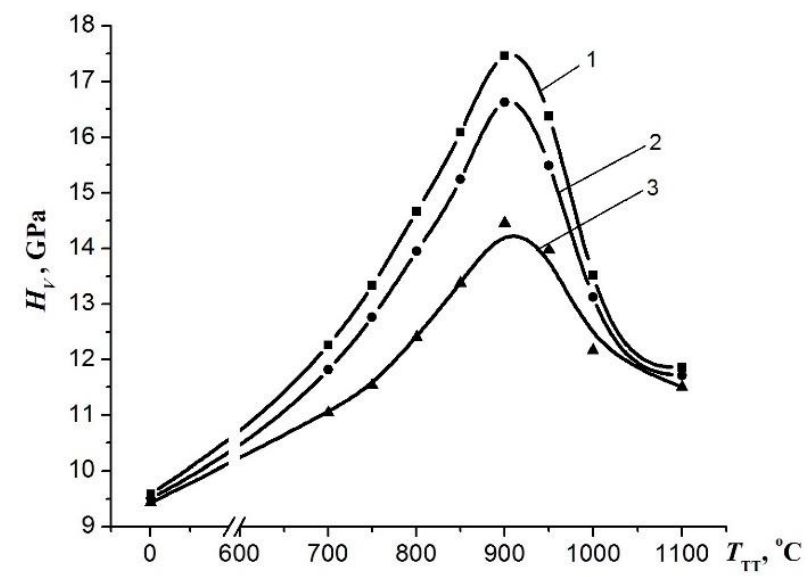

Fig. 4. Dependences of microhardness of samples $\mathrm{Si}[\mathrm{C}]_{1}$ (curve 1), $\mathrm{Si}[\mathrm{C}]_{2}$ (curve 2) and $\mathrm{KEF}-2$ (curve 3 ) on the temperature of their processing.
Amazingly, at room temperature, the microhardness of monocrystalline silicon becomes the leading rank for the rupture of irrelevant point defects and dislocations. Also, the growth of microhardness, in our view, can be associated with the increase in the concentration of domestic precipitates, which can lead to the blocking of point defects and dislocations.

Note that at room temperature, the microhardness of monocrystalline silicon is determined mainly by the mobility of nonequilibrium point defects and dislocations. Thus, the increase in microhardness, in our case, can be associated with an increase in the concentration of impurity precipitates, the appearance of which leads to blocking the movement of point defects and dislocations under the indenter of the microhardness tester.

The decrease in microhardness and paramagnetic component at annealing temperatures above $900{ }^{\circ} \mathrm{C}$ is obviously associated with a change in impurity-structural complexes in the crystals, which leads to a decrease in internal mechanical stresses. As shown in [15], the formation of dislocation loops predominates in this temperature range. This is confirmed by the results of studying structural defects in these crystals by photographing the etching surfaces of samples with a metallographic instrumental microscope (MIM-10). The obtained photographs of the etching surfaces are shown in Fig. 5.

In samples that were not temperature tritmented were mostly dominated by small etching pits of insignificant concentration. When the annealing temperature of the samples increases from $700{ }^{\circ} \mathrm{C}$ to $900{ }^{\circ} \mathrm{C}$, two tendencies are observed: 1) the concentration of etching pits with a size of $0.4-1 \mu \mathrm{m}$ decreases; 2 ) the concentration of small etching pits with the sizes of $0.1-0.2$ microns sharply increases.

Note that the following processes of oxygen precipitation and interstitial silicon atoms occur during heat treatment in $\mathrm{Cz}-\mathrm{Si}$ : oxygen precipitates with a large critical radius will grow for a given temperature, and with a smaller one they will decompose and participate in other complexation reactions, one of which is homogeneous oxygen precipitation, which can be represented by the following series of reactions:

$$
\begin{gathered}
O_{i}+O_{i} \stackrel{\chi_{2}, k_{2}}{\longrightarrow} O_{2}+S i_{i}, \\
O_{i}+O_{2} \stackrel{\chi_{3}, k_{3}}{\longrightarrow} O_{3}, \\
\quad \cdots \ldots \ldots \ldots \ldots \ldots \ldots \ldots \ldots \ldots \ldots \ldots \ldots \ldots \ldots \\
O_{i}+O_{k r} \stackrel{\chi_{k r+1}}{\longrightarrow} O_{k r+1} .
\end{gathered}
$$

where $\chi_{2}, \chi_{3}, \ldots \chi_{k r+1}$ are the rate constants of direct reactions; $k_{2}, k_{3}$ rate constants of inverse reactions.

Similar mechanisms will occur in the case of precipitation of internodal $\mathrm{Si}$ atoms, which will lead to the emergence of structural defects of the internodal type. This indicates that at a certain temperature and duration of annealing, some defects will grow and others will disintegrate.

Thus, an increase in the concentration of clusters on the one hand leads to an increase in microhardness (blocking the movement of point defects and dislocations 

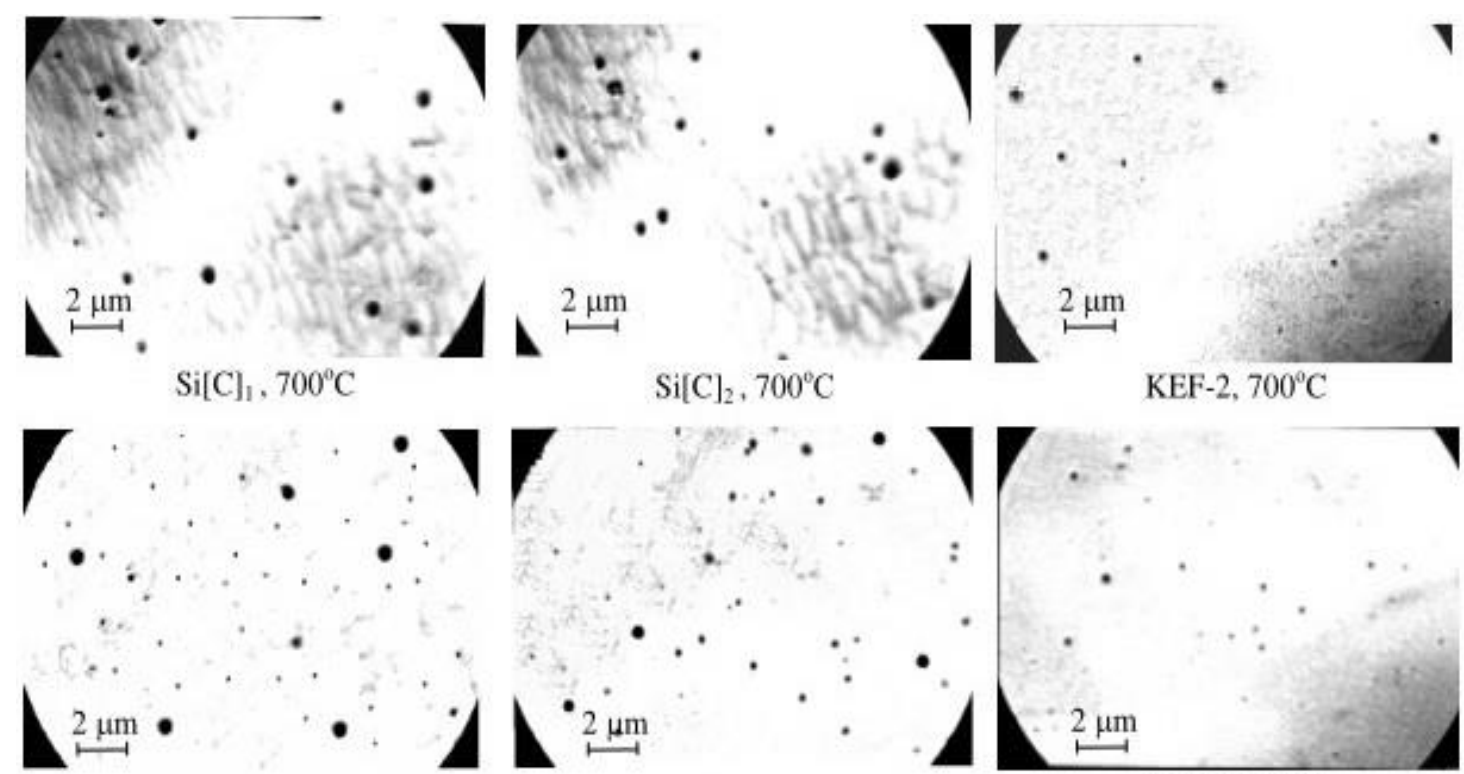

$\mathrm{Si}[\mathrm{C}]_{1}, 800^{\circ} \mathrm{C}$

$\mathrm{Si}[\mathrm{C}]_{2}, 800^{\circ} \mathrm{C}$

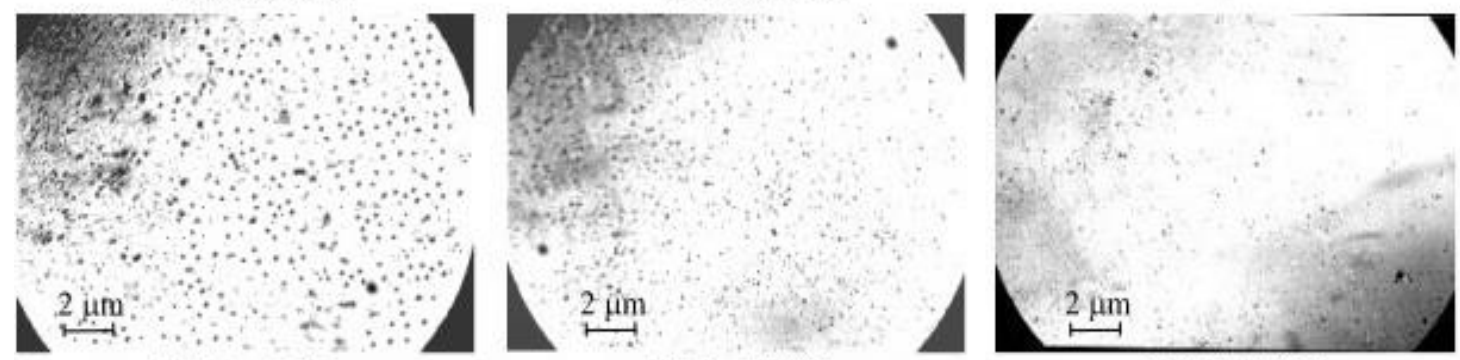

$\mathrm{Si}[\mathrm{C}]_{1}, 900^{\circ} \mathrm{C} \quad \mathrm{Si}[\mathrm{C}]_{2}, 900^{\circ} \mathrm{C}$

$\mathrm{KEF}-2,900^{\circ} \mathrm{C}$

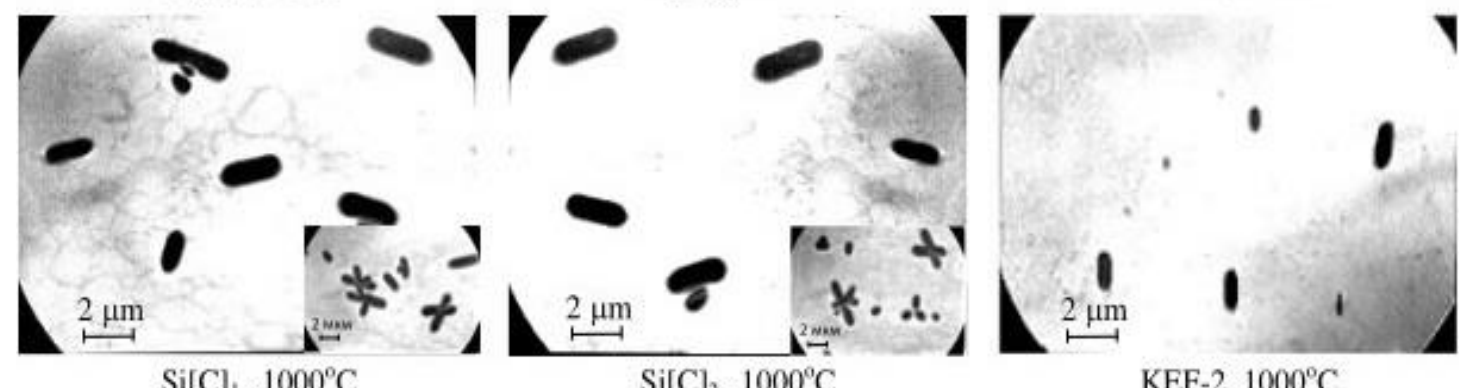

$\mathrm{Si}[\mathrm{C}]_{1}, 1000^{\circ} \mathrm{C}$

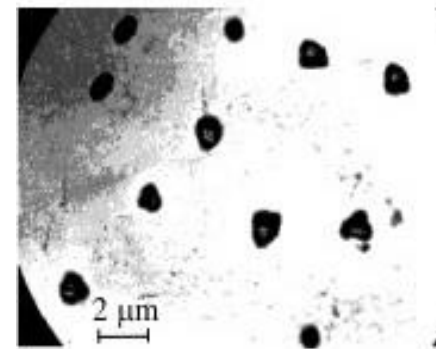

$\mathrm{Si}[\mathrm{C}]_{1}, 1100^{\circ} \mathrm{C}$

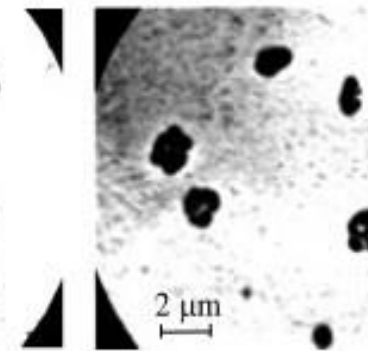

$\mathrm{Si}[\mathrm{C}]_{2}, 1100^{\circ} \mathrm{C}$

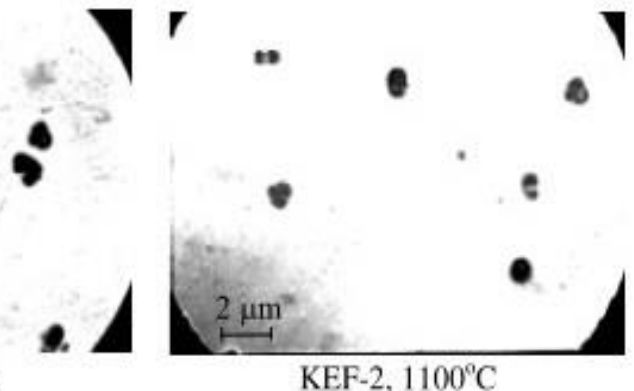

$\mathrm{KEF}-2,1100^{\circ} \mathrm{C}$

Fig. 5. Photographs of etching surfaces of samples.

under the indenter), and on the other - to an increase in the concentration of broken bonds, that is paramagnetism. Therefore, the obtained results fully confirm and explain the peculiarities of the behavior of magnetic susceptibility and microhardness.

At higher annealing temperatures, a sharp decrease in the concentration of defects and an increase in their size was detected. In particular, at $1000^{\circ} \mathrm{C}$ they have an elongated oval shape, and at $1100^{\circ} \mathrm{C}$ they are more rounded and form clusters. 


\section{Conclusions}

It is shown that heat treatment of single-crystal silicon in the temperature range $700-1100^{\circ} \mathrm{C}$ leads to the appearance of the paramagnetic component of their magnetic susceptibility. The magnitude of the paramagnetic component increases with increasing concentration of atomic carbon in the crystals. The maximum changes occur after heat treatment at $900^{\circ} \mathrm{C}$. In these samples, the concentration of magnetically ordered clusters was estimated and the function of their distribution by the magnitude of magnetic moments was constructed.

It was found that the detected changes in magnetic susceptibility correlate with changes in the microhardness of the samples after these heat treatments. The maximum value of microhardness was recorded after heat treatment of the samples at $900{ }^{\circ} \mathrm{C}$.

It is shown that the growth of the paramagnetic component of the magnetic susceptibility and microhardness of monocrystalline silicon, after heat treatment in the range of $700-1100^{\circ} \mathrm{C}$, is associated with the rearrangement of impurity-structural complexes at different annealing temperatures.

Pavlovskyy Yu.V. - Ph.D., Associate Professor, Associate Professor of Technological and Vocational Education;

Berbets O.V. - graduate student of the Educational and Scientific Institute of Physics, Mathematics, Economics and Innovative Technologies;

Litovchenko P.G. - Professor, Ph.D., Chief Researcher of the Department of Radiation Physics.

[1] C. Claeys, E. Simoen, V. Neimash, A. Kraitchinskii, M. Krasko, O. Puzenko, A. Blondeel, P. Clauws, Jornal of the Electrochemical Society, 148(12), G738 (2001); https://iopscience.iop.org/article/10.1149/1.1417558.

[2] M. David, E. Simoen, C. Claeys, V. Neimash, M. Kras'ko, A. Kraitchinskii, V. Voytovych, A. Kabaldin, J. Barbot, Journal of Physics: Condensed Matter, $17, \quad$ S2255 (2005); https://iopscience.iop.org/article/10.1088/0953-8984/17/22/013/meta.

[3] V.B. Neymash, V.V. Voytovych, A.M. Kraychyns'kyy, L.I. Shpinar, M.M. Kras'ko, V.M. Popov, A.P. Pokanevych, M.I. Horodys'kyy, Yu.V. Pavlovs'kyy, V.M. Tsmots', O.M. Kabal'din, Ukrainian Journal of Physics, 50(5), 492 (2005); http://archive.ujp.bitp.kiev.ua/files/journals/50/5/500513p.pdf.

[4] V.B. Neimash, V.V. Voitovych, M.M. Kras'ko, A.M. Kraitchinskii, O.M. Kabaldin, Yu.V. Pavlovs'kyi, $\begin{array}{lllll}\text { V.M. Tsmots', Ukrainian Journal of } & \text { Physics } & \text { 50(11), } & 1273 & \text { (2005); }\end{array}$ http://archive.ujp.bitp.kiev.ua/files/journals/50/11/501110p.pdf.

[5] C.A. Londos, E.N. Sgourou, D. Timerkaeva, A. Chroneos, Journal of Applied Physics 114, 113504 (2013); https://doi.org/10.1063/1.4821116.

[6] Deren Yang, Jia Chu, Jin Xu, Duanlin Que, Journal of Applied Physics 93(11), 8926 (2003); https://doi.org/10.1063/1.1569978.

[7] V.M. Tsmots', I.S. Pan'kiv, L.I. Pan'kiv, YU.V. Pavlovs'kyy, V.V. Petrenko, T.S. Kavets'kyy, D.V. Labovka, M.M. Luchkevych, R.V. Okhrymovych, V.P. Salan', M.V. Tsyuper, Patent Ukrayiny na vynakhid №77284 to 15.11.2006; https://iprop-ua.com/inv/ghuezi09/.

[8] S.G. Kazantsev, T.N. Ovcharenko, Voprosy $\quad$ elektromekhaniki $123, \quad 41 \quad$ (2011); http://jurnal.vniiem.ru/text/1234/41.pdf.

[9] V.S. Vavilov, V.F. Kiselev, B.N. Mukashev, Defekty v kremnii i na yego poverkhnosti (Nauka, Moskva, 1990).

[10] V.Ye. Kustov, M.G. Mil'vidskiy, Yu.G. Semenov, B.M. Turovskiy, V.I. Shakhovtsov, V.L. Shindich, Fizika i

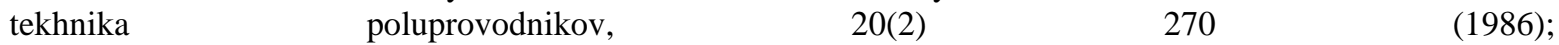
http://www.mathnet.ru/links/a86505ab46f6441b0d2e2de646e22bdf/phts60.pdf.

[11] D.Y. Tetel'baum, A.A. Ezhevskyy, A.N. Mykhaylov, Fizika i tekhnika poluprovodnikov, 37(11), 1380 (2003); https://journals.ioffe.ru/articles/5410.

[12] L.S. Vlasenko, M.P. Vlasenko, V.A. Kozlov, V.V. Kozlovskiy, Fizika i tekhnika poluprovodnikov 33(10), 1164 (1999); DOI: https://journals.ioffe.ru/articles/35875.

[13] P.G. Litovchenko, N.T. Pavlovska, Yu.V. Pavlovskyy, Yu.O. Ugrin, G. Luka, I.P. Ostrovskyy, Semiconductor Physics, Quantum Electronics \& Optoelectronics 17(4), 416 (2014); https://doi.org/10.15407/spqeo17.04.416.

[14] V.M. Tsmotsa, P.G. Litovchenkob, N.T. Pavlovskaa, Yu.V. Pavlovskyya, I. P. Ostrovskyy. Semiconductors, 44(5), 623 (2010); https://link.springer.com/article/10.1134/S1063782610050131.

[15] V.M. Tsmots, P.G. Litovchenko, N.N. Novikov, Yu.V. Pavlovskyy, H.M. Khlyap, M.M. Luchkevych, V.P. Salan, B.D. Patsai, Physica Status Solidi (A), 205(2), 368 (2008); https://doi.org/10.1002/pssa.200622104. 
Ю.В. Павловський ${ }^{1}$, О.В. Бербець ${ }^{1}$ П.Г. Литовченко ${ }^{2}$

\title{
Вплив ростових домішок на термічне дефектоутворення у монокристалічному кремнію
}

\footnotetext{
${ }^{1}$ Дрогобицький державний педагогічний університет імені Івана Франка, м. Дрогобич, Україна, уи_pavlovskyy@ukr.net ${ }^{2}$ Інститут ядерних досліджень НАН Украӥни, м. Київ, Україна
}

\begin{abstract}
Досліджено вплив ростових домішок (кисню та вуглецю) на магнітні, мікромеханічні та структурні властивості монокристалів кремнію, вирощених за методом Чохральського $(\mathrm{Cz}-\mathrm{Si})$, після їх термічної обробки (ТО) в інтервалі температур $700-1100{ }^{\circ} \mathrm{C}$. Вивчено розподіл дефектів, які утворюються при різних температурах відпалу. Виявлено кореляцію між змінами магнітної сприйнятливості, мікротвердості та перебудовою структурних дефектів у кристалах після їх термообробки. Оцінено концентрації та розміри магнітно впорядкованих кластерів. Запропоновано інтерпретацію одержаних експериментальних результатів.

Ключові слова: монокристалічний кремній, кисень, вуглець, магнітна сприйнятливість, мікротвердість, термічна обробка.
\end{abstract}

